\title{
RELIGIOUS AND SOCIO-ECONOMIC RELEVANCE OF POPE FRANCIS' VISIT TO ROMANIA
}

DOI: http://dx.doi.org/10.18509/GBP.2020.60

UDC: 272-732.2Francis, Pope(498)

\author{
Vasile Pop ${ }^{1}$ \\ Camellia Teodorescu ${ }^{2}$ \\ Irina-Valentina Radoi ${ }^{2}$ \\ Laurentiu Stefan Szemkovics ${ }^{3}$ \\ Nicoleta Bira ${ }^{4}$ \\ ${ }^{1}$ St. Elefterie Church, Bucharest, Romania \\ ${ }^{2}$ University of Bucharest, Faculty of Geography, Department of Human \\ and Economic Geography, CAIMT (Research Center for \\ Integrated Analysis and Territorial Management), Bucharest, Romania \\ ${ }^{3}$ National Central Historical Archives, Bucharest, Romania \\ ${ }^{4}$ Middle School "Spiru Haret" Oltenita City, Calarasi, Romania
}

\begin{abstract}
The present study tries a theological and socio-human approach at the same time, so that a correlation could be made between the religious beliefs of the world, in which life may be approached both from the perspective of the scientific data, as well as from the human thinking and up to the human feelings arisen and the beneficial influence Pope Francis' visit has exercised upon people up to the present time. To desacralize the world and life, means to diminish the real meaning and value, disregarding the entire spiritual edifice of humanity. The apostolic journey of Pope Francis that he made on the days of May 31June 2, 2019 in Romania, will remain not only a memory for all the Romanian people, but rather a historical event with a special spiritual charge, oriented towards reconciliation and tolerance between churches and ethnic groups, taking into account the multitude of ethnicities in Romania, of different denominations. The methodology was based on the collection of data from the online environment and the direct observations made by those who conducted the study, as a result of their taking part to the entire activity throughout their visit. The study is also supported by social surveys and discussions with the participants in the event, in the places where Pope Francis has held prayer talks and dialogues. The results highlight in the first place the large numbers of Romanians participating, regardless of ethnicity and religious affiliation, age or socio-professional structure, all having the same desire, that of maintaining a good understanding relationship among all Christians, no matter if Catholic or Orthodox. The culturalreligious pluralism in Romania is an advantage that we must all become aware of and that we must be glad about.
\end{abstract}

Keywords: religion, ethnicity, Pope Francis, cultural pluralism

\section{INTRODUCTION}

There is a great variety of churches and common faith communities, but the unity of the church has the utmost importance for the Christian religion [19], [14], [16]. This unity must be understood in an open and creative way so that each person could identify himself or herself in the ideas and all that the Christian church represents. Each individual, 
through the individual capacity of perceiving the messages transmitted by the Christian church, understands and can carry out their daily activity according to their own religious and cultural norms and principles [1], [7], [15]. On the other hand, the church must also be understood as a unit of creation, without ever breaking the unity. That unity is mainly the unity of faith in Jesus Christ [8], [10], [2]. The unity of the church is indeed nonnegotiable. However, there should be carefully examined the following questions to which the present study seeks to answer [2], [3], [9], need to be examined in depth. The most important questions are related to how the religious unity should be modeled and, more than that, how there can, and should be managed, the differences of worship cult [19], [17]. Therefore, unity and diversity are not contrasted but, on the contrary: the Catholics, Protestants and the majority constituted by the Orthodox people in Romania hold the idea of Christian unity. The visit of Pope Francis in Romania, the open reception and the massive assistance throughout the journey of His Holiness constitute once more a solid proof of this unity of Christian faith [4], [6].

Along with His Grace Daniel, Patriarch of Romania, Pope Francis during his visit to Romania was recognized as an expression of Christian unity. The Christian church must be understood as a unit of religious ideas because God is ONE and, regardless of worship type, all Christians maintain this uniqueness in their individual Christian culture. In receiving and enjoying the signs of communion, community unity is emphasized and this unity is expressed in Christ [11], [13]. This unity then has a special significance, because different people, regardless of race, creed, status or anything else, can find each other and glorify God [5].

In the discussions with those who participated and joined along the route of Pope Francis' visit to Romania, all believers hold the idea that we must be confident in our beliefs, that speaking of the unity of the believers does not simply refer to unanimity, uniformity or a reunion [6], [12].

In the context of the ecclesiology of communion, unity involves the spiritual nature and the devotion that enables the people of God to give a convincing testimony [18], [1]. God creates space for us by Him living, as well as by Him living our culture and sharing our experiences in it [17], [19]. In this way, the attitude can also lead to the reunion of the church in a unique and unitary way and can be built on the unity of faith and the dedication of this faith in the community [10]. The community that finds the deepest unity of faith in Jesus Christ will then strive to express the unity of the church in a pure, candid way. The unity of the church is not just a certain mentality of the people, but the unity of faith is also expressed by the way in which people send messages to one another, support one another, forgive one another, and achieve a future together. In the faith for Christ since forever, all Christian believers rely on mutual respect and building a Christian community is also based on respect and trust. In this sense, both the points of view, that of the Romanian Patriarchate and that of the Pope Francisc during his visit to Romania, consider that the attitude, the message transmitted and the unity of the church will bear particular significance, and the unity of the church will be found where people really respect each other [15].

Throughout the tour of the Romani visit, Pope Francis was accompanied by an impressive number of people, whose presence was due to religious and social belief [6], [16]. There were localities through which He only passed and other places where religious events took place (figure 1). 


\section{METHODOLOGY}

The method of analysis followed in the present study was an empirical one, based on the application of a questionnaire in the online environment and on discussions with those who participated at the events organized throughout the route where Pope Francis held discussions and prayer dialogues. The places where the Holy Father held prayer dialogues were Bucharest, Blaj, Sumuleu Ciuc and Iasi (figure 1). The participants were in a quite high number, and quite many of them wanted to complete the questionnaires, also participating directly, in a large number, as well as in the social survey conducted in the study. The openness of people to dialogue also resulted from this high share of study participation. The questionnaire was completed by specifying the localities in which they participated during this visit. Thus rom the localities through which the Holy Father passed, the number of completed questionnaires was as follows: in Bucharest, the questionnaire was completed by 476 people, in Blaj, by 213, in Sumuleu Ciuc it was completed by 201 people, while in Iasi, by 287 people. In total, the number of people who completed the questionnaire rose to 1177 . Also, in each locality of the ones mentioned previously, dialogues were held with those who participated. For graphical representation we proceeded at the common treatment of all questionnaires. In this way, the socioeconomic and religious interest of the Romanian population can be viewed as a whole, with respect to Pope Francis' visit to Romania. The results clearly indicate the religious benefit of the visit, in an overwhelming percentage, to which there is added that of the Romanian advertising, its emergence as a country with unity of faith on the politicalreligious map of the world. All these have a very important role for the correct perception of the image of Romania as a Christian country.

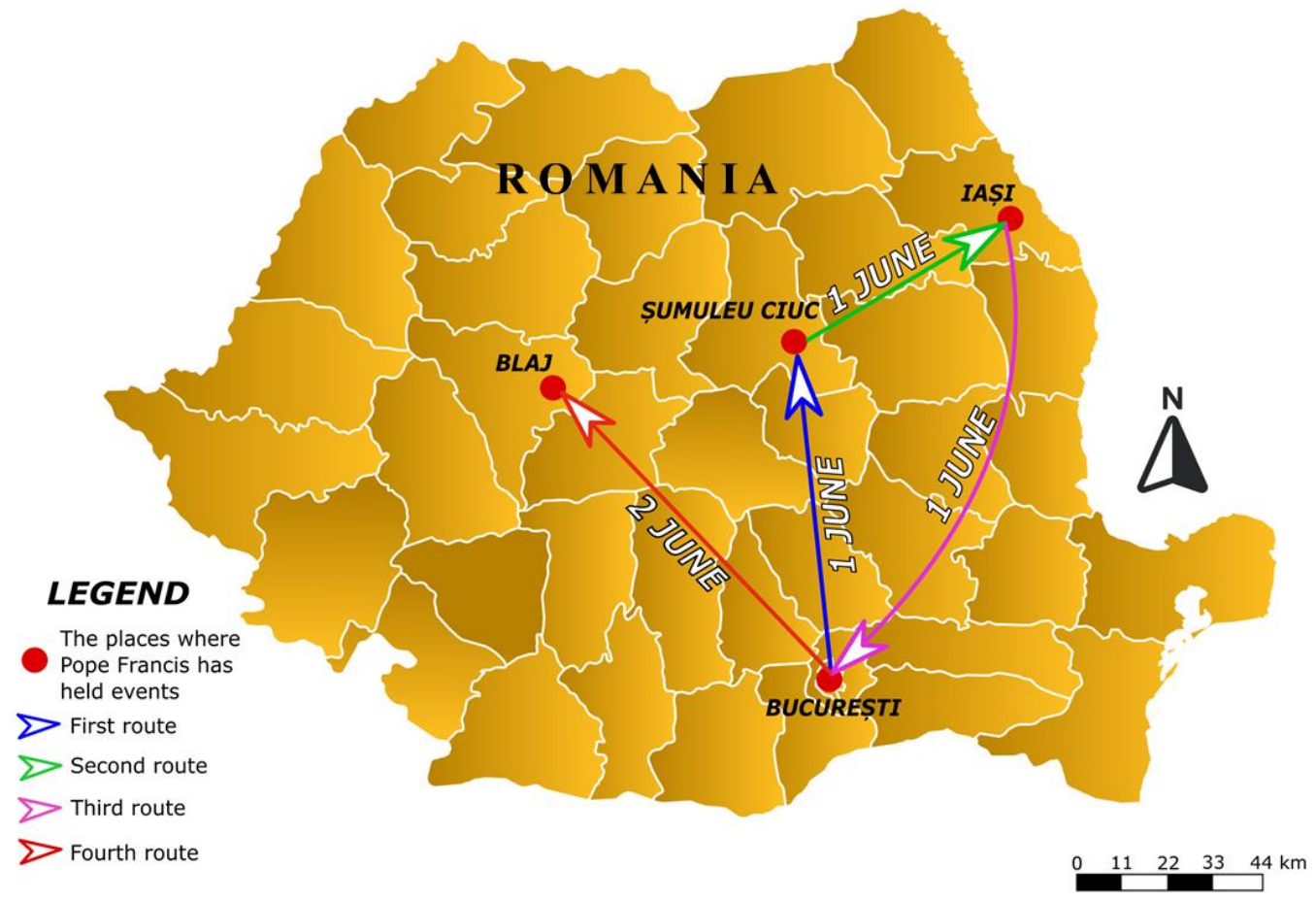

Figure 1. The route of Pope Francis's visit to Romania

\section{RESULTS AND DISCUSSIONS}

The results highlight first and foremost the large number of Romanian citizens participating, regardless of ethnicity and religious affiliation, age or socio-professional 
structure, all having the same desire, that of maintaining a good relationship of understanding between all Christians, no matter if Catholic or Orthodox. The culturalreligious pluralism in Romania is an advantage that we must all be aware of and that we must cherish.

Regarding the age of the participants, in the analysis of this study, most of them range between 18-45 years old (figure 2). This age segment is very important. This age group represents the main demographic component from the point of view of the labor force of the active population on the one hand, and on the other hand it is the basic component in representing the socio-cultural force.

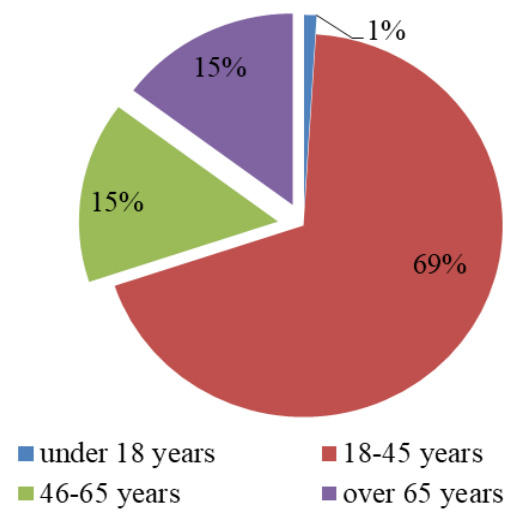

Figure 2. The structure by age groups of the study participants - the Pope's visit to Romania

Their cultural, religious, economic and social point of view can be found in future analyses, with changes depending on external factors. The maturity of those between 4665 years and those over 65 is also added.

From the point of view of religious affiliation, the Orthodox Christians, the majority religion in Romania, represent the largest share (figure 3).

This high share of Orthodox Christians, along with Catholics, cumulating GreekCatholics and Roman Catholics, is yet another proof of the Christian unity and of a common cultural vision of the population living in Romania.

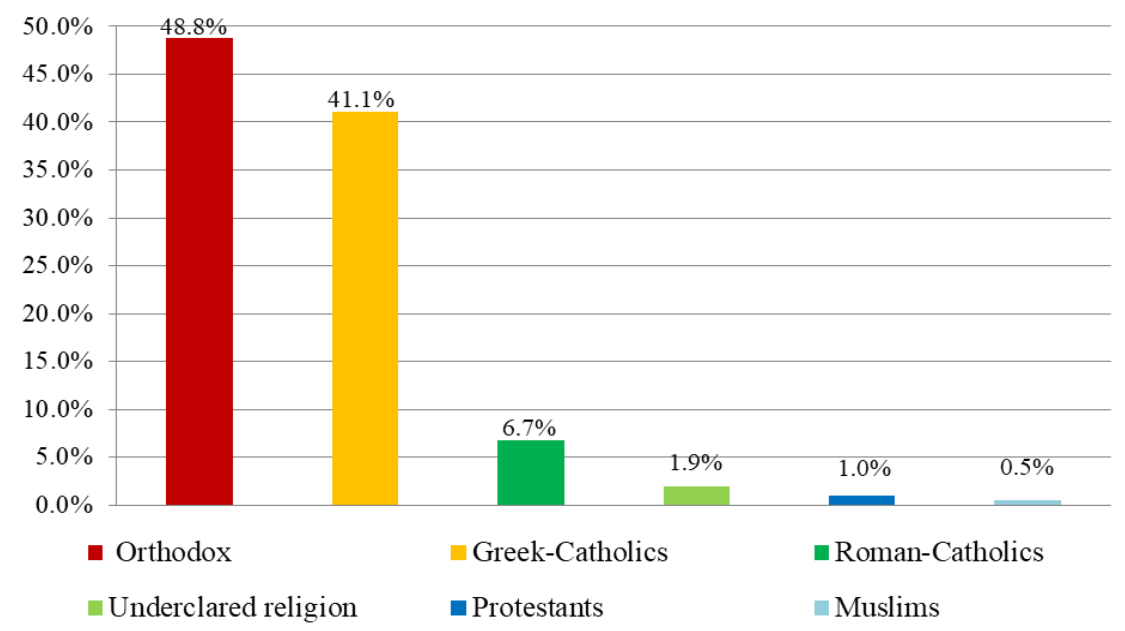

Figure 3. Religious apputernance of the study participants - Pope's visit to Romania

The benefits offered to the community are viewed differently by those who participated in the accomplishment of the study (figure 4). Those who gave a negative answer are more skeptical, rather than willing to give a clear, negative answer. The most of them, 
however, consider that a visit by a high representative of Christianity can only be of great significance, and the effects are beneficial from several points of view. The positive effects are found both in the direct consumption of the participants in the religious event, and indirectly, through the advertising brought to Romania as a result of the degree of religious and social security in Romania.

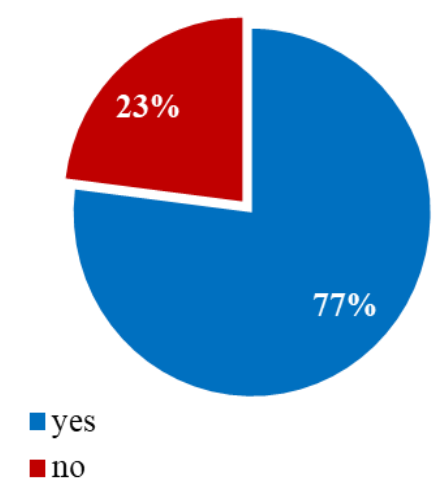

Figure 4. The beneficial effects of Pope Francis' visit from perspective of the population participating in the study

As a novelty, the present study forwards the image of the Romanian Orthodox population, by underlying the need for dialogue and reunion, starting from the premise that multiculturalism is a win, as well as the way in which multiculturalism was conceived, ideologically and especially socio-politically [7]. The clear effects on the areas where benefits can be brought as a result of the visit of the Holy Father in Romania, following the application of the questionnaires, show the religious importance of the event (figure 5).

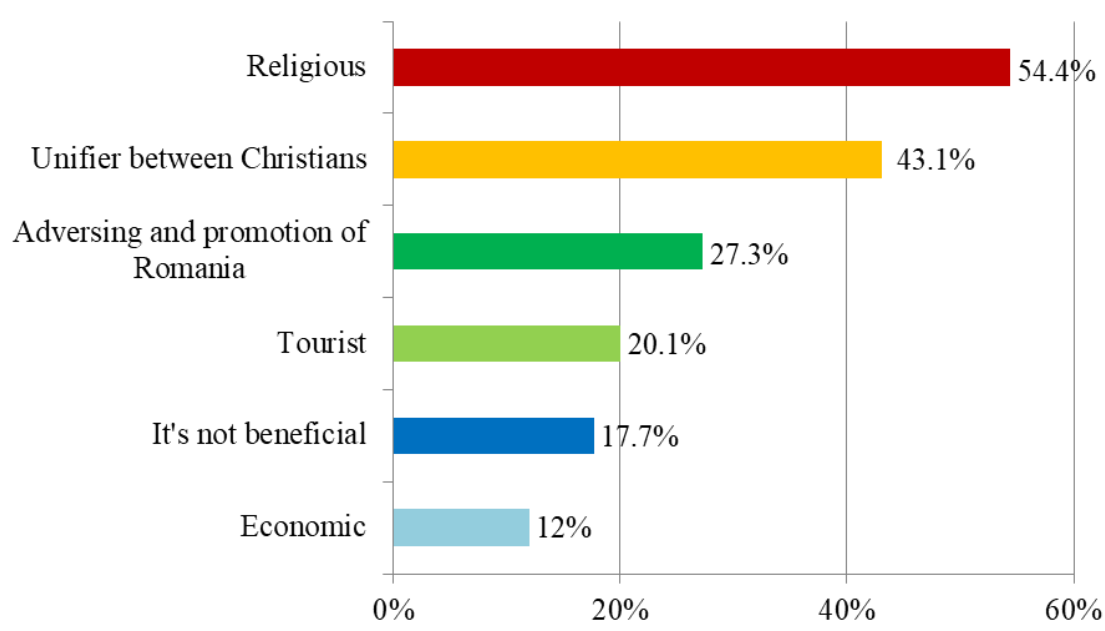

Figure 5. The areas which the benefits of the Pope Francis' visit to Romania are brought from the perspective of the study participants

The population of Romania emphasizes through the answers given this need to maintain a Christian unity, not only at the level of Romania, but also at the level of the entire Europe. Christianity can contribute to maintaining religious balance, to maintaining a common reason, to economic development and to moral and behavioral ethics, to creating a system of real values [7]. Economic and technological development without maintaining rational ethics is fragile. Ghibanu argues in his writings a very important thing, that according to which "Christian spirituality gives birth to the following values: 
belief in progress, hope for a better world, sense of history, marriage and monogamous family, freedom, justice, work ethics, tolerance, non-discrimination, subsidiarity, participation and solidarity".

This idea is expressed in a simple manner by the Romanian population, by completing the questionnaires. The researchers in the field of religion come with clear explanations, they come with their word and lectures in support of the population, who, by their gestures and by what they try to do, say the same thing. Collaboration is very important. The exchange of ideas, communication is the most important thing and must be taken into account. The church can contribute to the culture of sustainability by communicating a vision upon life and to equal extent it inspires forms of behavior that give the sustainability resistance.

\section{CONCLUSIONS}

The article promotes an ideology policy and emphasizes the role of religion in Europe, especially the idea that inter-religious and ecumenical dialogue is a European creation, and that freedom, tolerance, respect for otherness and dignity of others are also conceived with a strong European brand and, why not, a Christian one. Pope Francis' visit to Romania is a proof of this unity of ideas and a clear expression of Christendom's tolerance. Romanians are mostly Orthodox. This did not prevent them from being close to their fellow Christian Catholics and His Holiness, by offering openly the warmth with which, in the first place, a good Christian must be received. On the other hand, Romania has undergone a difficult period from the economic and social point of view, with the transition from one type of economy to another, from communism to democracy. This passage also favored openness to faith. The communist period did not allow human communication with the church. Despite these restrictions, people did not cease to have openness to faith and to the church. After 1989, freedom of speech and, first of all, freedom of religious expression created the ease of man finding himself in the Christian idea. It is an extraordinary thing in terms of freedom of thought and Christian expression. Pope Francis' visit to Romania also aroused a socio-economic interest regarding the mentality of the Romanian population. The publicity brought to Romania due to this event is considered to be very important. The economic importance is noticeable directly through consumption. All those participating in the event resorted to the accommodation infrastructure in the localities where the events took place, respectively Bucharest, Blaj, Sumuleu Ciuc and Iasi, but also in the neighboring localities. Also, food consumption can also be regarded as a significant economic parameter during this visit with direct economic effects. Indirectly, the religious publicity and the tolerance or hospitality of the Romanians equally contribute to the positive social and economic effect brought about by this important religious event.

The study brings, as a novelty, the expression of European religious desire. It is a common wish, expressed both by His Most Blessed Father Daniel, the Patriarch of Romania and His Holiness, Pope Francis, but it must be maintained from all points of view, having as its basis the religious perspective, as a binder for the other components: the economic, political and military ones. The foundations of a stable world and a sustainable European civilization are laid under the conditions of a Christian unity, which has the role of maintaining cultural identity. Communication and especially ecumenical dialogue are necessary, and tolerance, respect for the dignity of others are European and Christian concepts. These are clearly expressed in the study by all those who participated to the events all through the three days of Pope Francis' visit to Romania. 


\section{REFERENCES}

[1] Alvarez J.J., To exist with and for the people: Philosophico-Religious roots and the need of a moral common faith, Politics and Religion Journal, vol.13, issue 1, pp 97-112, 2019

[2] Barrera-Fernandez D., Hernandez-Escampa M., The impact of urban policy in the management of the tourist-historic city: a comparative study, Pasos-Revista de Turismo y Patrimonio Cultural, vol. 14, Issue 3, pp 705-724, 2016

[3] Besschetnova Elena, The idee of Christian Unity at the End of the Nineteenth Century, Church History and Religious Culture, vol. 99, Issue 1, pp 46-63, 2019

[4] Costa Hilário, Ana Catarina; Marreiro das Chagas, Márcio, Influencia del escultismo en la formación personal y social de los scouts por medio de la práctica del turismo ecológico y pedagógico, Estudios y Perspectivas en Turismo, vol. 23, Issue 3, pp 484-50, 2014

[5] Dietrich Stephanie, God's Mission as a call for Transforming Unity, International Review of Mission, vol.107, Issue.2, pp 378-390, 2015

[6] Dincă Iulian \&Teodorescu Camelia, The Romanian rural space and its landscapes: attraction and motivation for relocating townspeople, Geographia Napocensis, vol. 1, pp 21-36, 2015

[7] Ghibanu Ionut Adrian, Inter-Religious and Inter-Christian Dialogue - a Contemporary Ecclesial Educational Priority, Revista Romaneasca pentru Educatie Multidimensionala, vol.10, Issue. 2, pp 36-44, 2018

[8] Ghibanu Ionut Adrian, Religious Identity and Multicultural Dialogue in Contemporary Europe, $2^{\text {nd }}$ Central \& Eastern Lumen International - Multidimensional Education \& Professional Development, Ethical Value (MEPDEV), $2^{\text {nd }}$ Edition, European Proceedings of Social and Behavioural Science, vol. 27, pp 234-240, 2017

[9] Herman G.V., Varnav R., Design elements for promoting attraction case study: Tara Oasului museum (Satu Mare County), Geojournal of tourism and geosites, vol. 14 / issue 2, Oradea, Romania, pp 168-177, 2014

[10] Herms Eilert, The Contribution of the Christian churches to a Culture of Sustenability or: The Christian Culture of Sustenability, Zeitschrift Fur Evangelische Ethik, vol. 62, Issue 2, pp. 115-128, 2018

[11] Hocaoglu D.A., The Role of Design in Cultural Heritage Based City Branding of Beypazari, Milli Folklor, vol. 109, pp 217-232, 2016

[12] Ilieș D.C., Baias Ș., Buhaș R., Ilies A., Herman G.V., Gaceu O., Dumbrava R., Măduța F.M., Environmental education in protected areas. Case study from Bihor county, Romania, Geojournal of tourism and geosites, vol. 19 / issue 1, pp 126-132, 2017

[13] Knop Iulia, The Diaconate as a Dimension of the Diaspora Church, Internationale Kattholische Zeithschrift Communio, vol.1, Issue 3, pp 216-228, 2018

[14] Kopiec Piotr, The idea of the Biblical economics: Utopia or chance in the of the contemporary transformation of the sphere of work, HTS Teologiese Studies-Theological Studies, vol. 75, Issue 4, 2019

[15] Oliver Willem H., Erna, God as One, HTS Teologiese Studies-Theological Studies, vol. 75, Issue 1, 2019

[16] Radu-Daniel Pintilii, Daniel Peptenatu, Ana-Maria Ciobotaru, Sorin George Toma, Ana Maria Grigore, Cristian-Constantin Drăghici, Răzvan-Cătălin Dobrea, Adrian Gabriel Simion, Ion Andronache, Camelia Teodorescu, Daniel Constantin Diaconu, Creative economies in Romania-spatial projections and trends, Bulletin of Geography. Socio-Economic Series, Vol. 37. pp 95-108, 2017 
[17] Teodorescu Camelia, Octavian Teodorescu, Nicoleta Bira, Badea Alin, Badea Livia Florina, Religious and cultural tourism and the socio-economic and educational implications, Quaestus Multidisciplinary Research Journal, vol. 8, pp 227-285, 2016

[18] Teodorescu Camelia, Radu-Daniel Pintilii, Peptenatu Daniel, Teodorescu Octavian, Toma Sorin George, Popularizing Cultural Identity Through Religious Tourism-Socio-Economic and Educational Implications, International Multidisciplinary Scientific GeoConference: SGEM: Surveying Geology \& mining Ecology Management, vol.3, pp 947-954, 2016

[19] Vester Pieter, Challenges of the diversity of languages in churches: The unity of the church and language, Tydskrif Vir Geesteswetenskappe, vol. 59, Issue 2, pp 192-202, 2019 